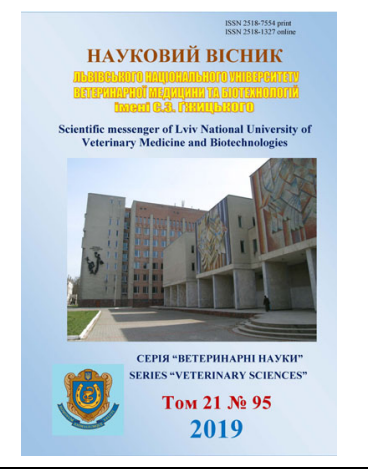

\author{
Науковий вісник Дьвівського національного університету \\ ветеринарної медицини та біотехнологій імені С.3. Гжицького. \\ Серія: Ветеринарні науки
}

Scientific Messenger of Lviv National University of Veterinary Medicine and Biotechnologies.

Series: Veterinary sciences

\title{
Historical aspects and epizootic situation of the porcine epidemic diarrhea
}

\author{
D.M. Masiuk, V.V. Glebenyuk, A.V. Kokarev, T.O. Vasylenko
}

Research Center for Biosafety and Environmental Control of AIC Dnipro State Agrarian and Economic University, Dnipro, Ukraine

Article info

Received 10.09.2019

Received in revised form 10.10.2019

Accepted 11.10.2019

Research Center for Biosafety and Environmental Control of AIC Dnipro State Agrarian and Economic University, Serhiya Yefremova Str., 25, Dnipro, 49000, Ukraine.

Tel.: +38-050-636-62-37

E-mail: dimasiuk@gmail.com
Masiuk, D.M., Glebenyuk, V.V., Kokarev, A.V., \& Vasylenko, T.O. (2019). Historical aspects and epizootic situation of the porcine epidemic diarrhea. Scientific Messenger of Lviv National University of Veterinary Medicine and Biotechnologies. Series: Veterinary sciences, 21(95), 75-79. doi: $10.32718 /$ nvlvet9513

The development of an epizootic situation for emergent infections is characterized by the emergence of the pathogen beyond the borders of countries and even continents. In some developed countries, the epizootic situation of PED is complex and tense. The emergence of the disease is facilitated by various factors: insufficient level of biosecurity and biosafety of farms, lack of information on the spread of infection, mechanisms of transmission of the pathogen, lack of effective means of specific prevention, etc. Changing the form of the epizootic process and the emergence of PED outbreaks in new territories have caused economic consequences for pork producers in the USA, China, South Korea, Thailand, Vietnam and others. The purpose of our work was to identify the historical aspects and epizootic situation about the PED. Scientific publications were used to analyze epizootic data. In studying the epizootic situation of PED in Ukraine, the results of laboratory studies of the Research Center for Biosafety and Environmental Control of the Agroindustrial Complex of the Dnipro State Agrarian and Economic University during 2015-2018 were used. The first is from the time of the description of the disease until 2010. During this period, there was a gradual spread of PED to European and Asian countries. Epizootic outbreaks of the disease were rare and isolated, and in certain territories were enzootic. The second-from 2010 and to the present. As a result of the genome mutation, the PED virus has acquired high virulence and emergent properties. There was a transcontinental introduction of the pathogen and rapid expansion of the nosoareal of the disease. The epizootic process of PED is characterized by epizootic and panzootic forms of manifestation. Despite preventive and well-being anti-epizootic measures, the epizootic situation regarding PED in Ukraine is consistently unfavorable: Zaporizhzhia, Cherkasy, Dnipropetrovsk and Kharkiv regions were identified as the most unfavorable in relation to the PED.

Key words: porcine epidemic diarrhea, evolution, nosoareal, spread, virulence.

\section{Історичні аспекти та епізоотична ситуація щодо епідемічної діареї свиней}

\author{
Д.М. Масюк, В.В. Глебенюк, А.В. Кокарєв, Т.О. Василенко
}

Науково-дослідний иентр біобезпеки та екологічного контролю ресурсів АПК, Дніпровський державний аграрно-економічний університет, м. Дніпро, Україна

Розвиток епізоотичної ситуації щуодо емерджентних інфекцій характеризується виходом збудника за межі крайн і навіть континентів. У низиі розвинутих країн епізоотична ситуація щчодо ЕДС є складною і напруженою. Виникнення захворювання спричиняють різні фактори: недостатній рівень біобезпеки та біозахисту господарств, відсутність інформації про поширення інфекиії, механізмів передачі збудника, відсутність ефективних засобів специфічної профілактики і т. д. Зміна форми прояву епізоотичного прочесу та виникнення спалахів ЕДС на нових територіях спричинило значні економічні наслідки виробникам свинини в США, Китаї, Південній Кореї, Таӥланді, В'єтнамі та ін. Метою нашої роботи було визначення історичних аспектів та епізоотичної ситуації щ⿻одо ЕДС. Для проведення аналізу епізоотичних даних використовували дані наукових публікацій. Під час вивчення епізоотичної ситуації щодо ЕДС в Україні використовували результати лабораторних досліджень Науково-дослідного центру 
біобезпеки та екологічного контролю ресурсів агропромислового комплексу Дніпровського державного аграрно-економічного університету впродовж 2015-2018 рр. На основі результатів досліджень встановлено, щуо в історичному аспекті еволюиї ЕДС виділено два періоди. Перший - з часу опису хвороби до 2010 р. У цей період відбувалося поступове поширення ЕДС краӥнами Європи та Азї. Епізоотичні спалахи хвороби були рідкими та поодинокими, а на певних територіях мали ензоотичний характер. Другий - з 2010 р. і донині. Внаслідок мутаиї геному вірус ЕДС набув високої вірулентності та емерджентних властивостей. Відбулося трансконтинентальне занесення збудника та стрімке розширення нозоареалу хвороби. Епізоотичний процес ЕДС характеризувався епізоотичним та панзоотичним формами прояву. Незважаючи на проведення профілактичних та оздоровчих протиепізоотичних заходів, епізоотична ситуачія щзодо ЕДС в Україні є стабільно неблагополучною. Найбільш неблагополучними щзоо ЕДС визначено Запорізьку, Черкаську, Дніпропетровську та Харківську області.

Ключові слова: епідемічна діарея свиней, еволючүія, нозоареал, поширення, вірулентність.

\section{Вступ}

Розвиток епізоотичної ситуації щодо емерджентних інфекцій характеризується виходом збудника за межі країн і навіть континентів. До таких хвороб належить епідемічна діарея свиней (ЕДС), яка характеризується діарейним синдромом та високою захворюваністю і смертністю, особливо підсисних поросят. У поросят, які захворіли упродовж декількох діб виявляють анорексію, водянисту діарею, блювання, дегідратацію (Masiuk et al., 2017).

У низці розвинутих країн епізоотична ситуація щодо ЕДС є складною і напруженою. Виникнення захворювання спричиняють різні фактори: недостатній рівень біобезпеки та біозахисту господарств, відсутність інформації про поширення інфекції, механізми передачі збудника, брак ефективних засобів специфічної профілактики тощо (Pasick et al., 2014).

Зміна форми прояву епізоотичного процесу та виникнення спалахів ЕДС на нових територіях спричинило значні економічні наслідки виробникам свинини в США, Китаї, Південній Кореї, Таїланді, В'єтнамі та ін. Так, щорічні економічні збитки від ЕДС в США становили від 0,9 до 1,8 млрд доларів і пов'язані 3 високою летальністю поросят та зниженням продуктивності у відгодівельних тварин (Paarlberg, 2014). Одне із завдань світової епізоотології полягає у 3'ясуванні причин емерджентності інфекцій та динаміки їхнього поширення на нових ареалах. Саме тому метою нашої роботи було визначення історичних аспектів та епізоотичної ситуації щодо ЕДС.

\section{Матеріал і методи досліджень}

Для проведення аналізу епізоотичних даних використовували дані наукових публікацій, повідомлень МЕБ, інтернет-ресурсів тощо.

Під час вивчення епізоотичної ситуації щодо ЕДС в Україні використовували результати лабораторних досліджень Науково-дослідного центру біобезпеки та екологічного контролю ресурсів агропромислового комплексу Дніпровського державного аграрноекономічного університету впродовж 2015-2018 pp.

Моніторингові дослідження щодо поширення ЕДС в Україні охопили $21(84 \%)$ із 25 регіонів України: Вінницький, Волинський, Дніпропетровський, Донецький, Закарпатський, Запорізький, Житомирський, Івано-Франківський, Київський, Кіровоградський, Львівський, Полтавський, Сумський, Тернопільський,
Одеський, Харківський, Херсонський, Хмельницький, Черкаський, Чернівецький та Чернігівський.

Для проведення лабораторних досліджень від хворих тварин відбирали зразки біологічного матеріалу (сироватку крові, фекалії, уражені ділянки кишечнику). Зразки сироватки досліджували за допомогою імуноферментного методу 3 використанням тестсистеми ID Screen®PEDV Indirect (виробник IDvet, Франція). Індикацію віруса ЕДС у біологічному матеріалі здійснювали методом ПЛР 3 використанням тест-системи EZ-RED/TGE/PDCoV MPX 1.0 Realtime RT-PCR (Tetracore, CШA).

\section{Результати та їх обговорення}

Уперше ЕДС було описано в 1971 р. у Великобританії як захворювання, подібне до трансмісивного гастроентериту свиней (Wood, 1977). У 1978 р. в Бельгії під час спалахів захворювання на чотирьох свинофермах було виділено вірус, який за експериментального зараження свиней спричиняв відтворення хвороби з характерним проявом клінічних ознак. Це обгрунтувало визначення цього вірусу як етіологічного агента ЕДС (Pensaert \& Bouck, 1978). Упродовж наступних трьох десятиліть вірус ЕДС виявили у низці європейських країн: Угорщині, Італії, Німеччини, Франції, Швейцарії та Чехії, і до 2005 року збудник хвороби викликав рідкі поодинокі спалахи в Європі. За цих умов, захворювання частіше траплялося у дорослих свиней, а в поросят клінічні ознаки були відсутні або слабко проявлялися.

У 2005-2006 рр. в Італії лабораторними дослідженнями було підтверджено діагноз на ЕДС на 63 фермах. Смертність неонатальних поросят сягала $34 \%$. У дорослих тварин захворюваність становила від 20 до $80 \%$ з низькою смертністю. Клінічний період хвороби тривав від одного тижня до місяця (Martelli et al., 2005).

В Азії хворобу було вперше діагностовано в 1982 році і донині прояв епізоотичного процесу вважається ензоотичним, що призводить до суттєвих економічних втрат для виробників свинини в Китаї, Південній Кореї, Таїланді і В'єтнамі (Song \& Park, 2012). Серологічним моніторингом, проведеним у Південній Кореї протягом 2007 р. виявлено позитивний статус тварин в 91,8\% (зі 159) свиногосподарств, що вказує на значне поширення ЕДС на території країни.

3 2010-2011 pp. у багатьох провінціях Китаю спостерігалося значне збільшення кількості спалахів ЕДС, що характеризувалися 80-100\% захворюваністю 
і 90\% смертністю. Зміна інтенсивності прояву епізоотичного процесу була спричинена появою нового високовірулентного штаму віруса. Крім того було встановлено, що поява збудника хвороби зі зміненими біологічними властивостями відбулося внаслідок мутації його геному (Li et al., 2012).

Спочатку епізоотичні спалахи ЕДС були описані на території азійських країн: Південній Кореї, Китаю, Тайвані (Park et al., 2014; Sung et al., 2015). Згодом - у 2013 р. зі США вірус ЕДС занесено до Канади, Мексики, Еквадору (Pasick et al., 2014; Barrera et al., 2017; Lara-Romero et al., 2017). За цих умов, у США вірус ЕДС був швидко поширений i спричинив загибель більше мільйона тварин у 32 штатах.

На основі молекулярних досліджень встановлено генетичну спорідненість штамів вірусу ЕДС, уперше ізольованих у США в 2013 році та циркулюючих у Китаї впродовж 2011-2012 років (Chen et al., 2014).

Починаючи з 2014 року, в країнах Європи повідомлено про ЕДС в Італії, Австрії, Португалії, Бельгії, Сербії, Франції, Німеччині, Угорщині, Україні
(Dastjerdi et al., 2015; Masiuk et al., 2017; ProdanovRadulović et al., 2017).

Європейські штами вірусу ЕДС, ізольовані 3 2014 року, належать до групи S INDEL, що включають низьковірулентні штами та викликають доброякісний перебіг ЕДС та меншу захворюваність і летальність. Аналіз секвенування повних геномів продемонстрував, що S INDEL штами ЕДС, що циркулюють у країнах Свропи, мають низьку схожість з високовірулентними штамами зі Сполучених Штатів Америки та Китаю. Водночас вони відрізняються від європейських штамів, виділених до 2014 р. (Hanke et al., 2015).

Під час моніторингових досліджень в Україні ЕДС було підтверджено в $14(66,67 \%) 321$ регіону України: Вінницькому, Дніпропетровському, Закарпатському, Запорізькому, Житомирському, Київському, Львівському, Полтавському, Одеському, Харківському, Херсонському, Хмельницькому, Черкаському та Чернігівському. Благополучними щодо ЕДС були свиногосподарства Волинського, ІваноФранківського, Тернопільського, Чернівецького, Донецького та Сумського регіонів (рис. 1).

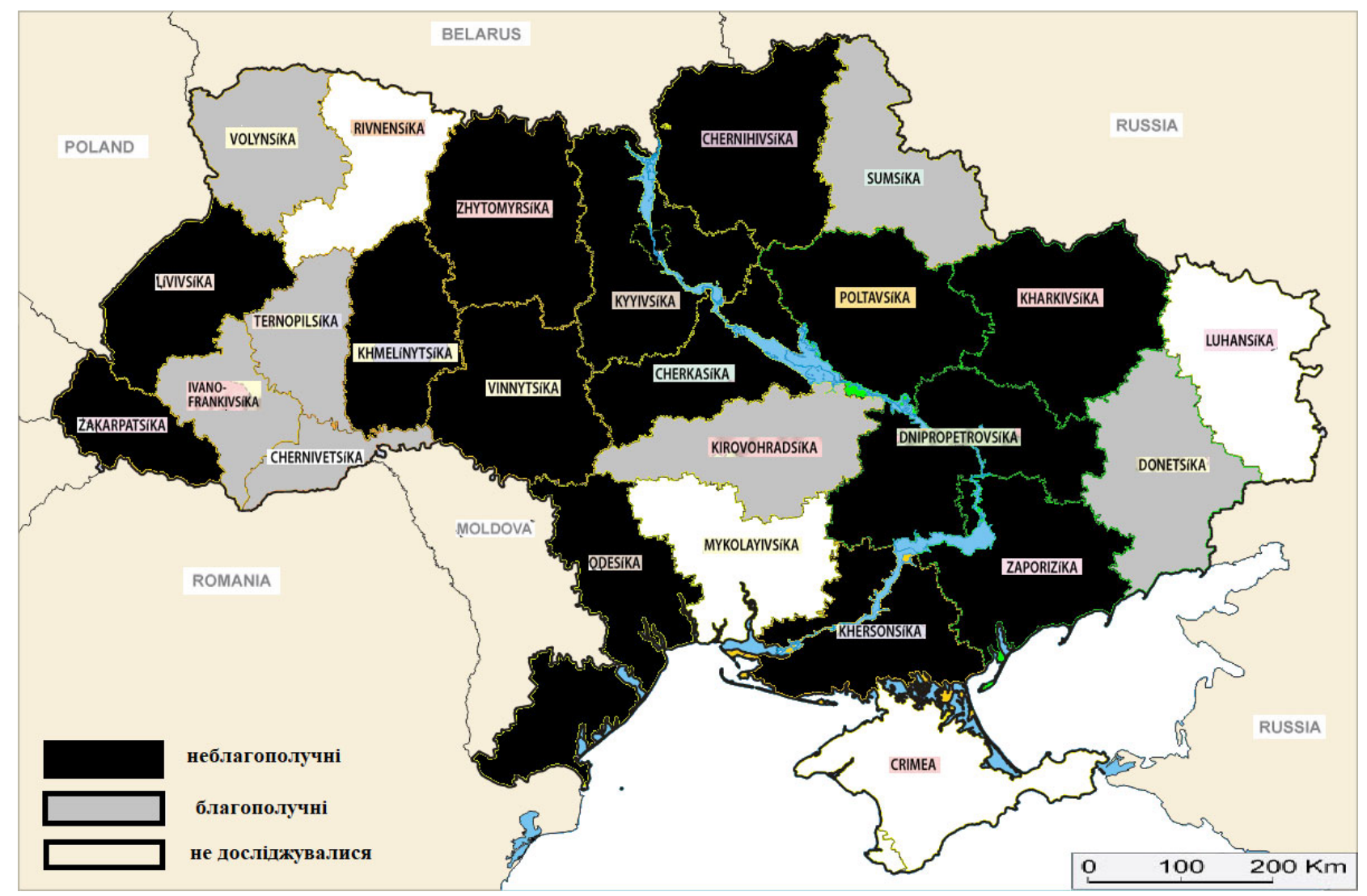

Рис. 1. Карта епізоотичної ситуації щодо епідемічної діареї свиней в Україні за результатами досліджень НДЦ біобезпеки та екологічного контролю ресурсів АПК ДДАЕУ упродовж 2015-2018 pp.

Упродовж усього періоду досліджень наявність вірусу ЕДС підтверджено метод ПЛР у 28,0\% (369 із 1317) зразків біологічного матеріалу, а наявність ан- титіл до збудника хвороби у 3,1\% (29 із 921) зразків сироватки крові (рис. 2). 
A

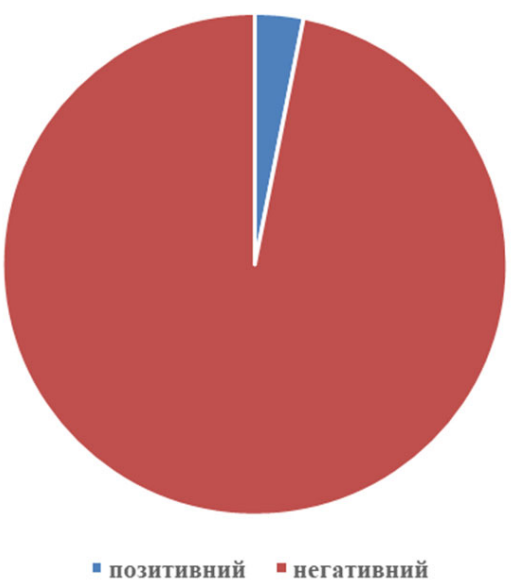

B

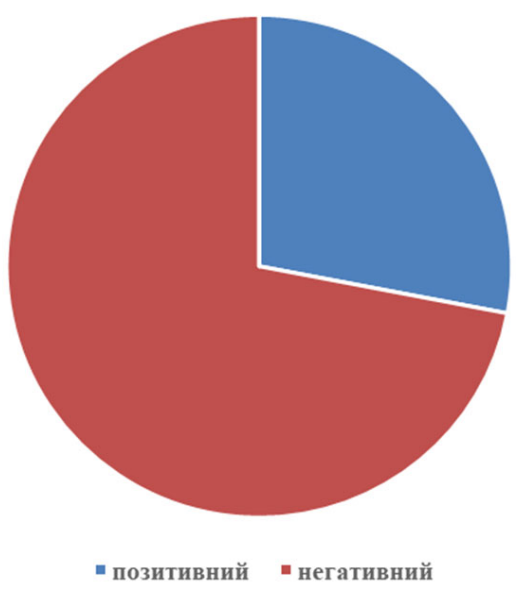

Рис. 2. Результати лабораторних досліджень на ЕДС із використанням ІФА (А) та ПЛР (В), проведених у НДЦ біобезпеки та екологічного контролю ресурсів АПК ДДАЕУ впродовж 2015-2018 pp.

Найбільш неблагополучними (30-50\% позитивних випадків) щодо ЕДС визнано Запорізьку, Черкаську, Дніпропетровську та Харківську області.

Отже, в історичному аспекті ЕДС виділено два періоди:

- перший - 3 часу опису хвороби до 2010 р. У цей період відбувалося поступове поширення ЕДС у країнах Європи та Азії. Епізоотичні спалахи хвороби були рідкими та поодинокими, а на певних територіях мали ензоотичний характер;

- другий - з 2010 р. і донині. Внаслідок мутації геному вірус ЕДС набув високої вірулентності та емерджентних властивостей. Відбулося трансконтинентальне занесення збудника та стрімке поширення нозоареалу хвороби. Для епізоотичного процесу ЕДС характерний епізоотичний та панзоотичний форми прояву.

\section{Висновки}

В історичному аспекті виділено два періоди еволюції епідемічної діареї свиней, що характеризуються різними формами прояву епізоотичного процесу та динамікою епізоотичної ситуації. Незважаючи на проведення профілактичних та оздоровчих протиепізоотичних заходів, епізоотична ситуація щодо ЕДС в Україні є стабільно неблагополучною. Найбільш неблагополучними щодо ЕДС визнано Запорізьку, Черкаську, Дніпропетровську та Харківську області.

Перспективи подальших досліджень полягають у вивченні молекулярної характеристики вірусу епідемічної діареї свиней.

\section{References}

Barrera, M, Garrido-Haro, A, Vaca, M.S., Granda, D., Acosta-Batallas, A., \& Pérez, L.J. (2017). Tracking the Origin and Deciphering the Phylogenetic Relationship of Porcine Epidemic Diarrhea Virus in Ecuador. BioMed research international, ID 2978718. doi: $10.1155 / 2017 / 2978718$.
Chen, Q., Li, G., Stasko, J., Thomas, J.T., Stensland, W.R., Pillatzki, A.E., Gauger, et al. (2014). Isolation and characterization of porcine epidemic diarrhea viruses associated with the 2013 disease outbreak among swine in the United States. Journal of clinical microbiology, 52(1), 234-243. doi: 10.1128/JCM.02820-13.

Dastjerdi, A., Carr, J., Ellis, R.J., Steinbach, F., \& Williamson, S. (2015). Porcine epidemic diarrhea virus among farmed pigs, Ukraine. Emerg. Infect. Dis., 21, 2235-2237. doi: 10.3201/eid2112.150272.

Hanke D, Jenckel M, Petrov A, Ritzmann M, Stadler J, Akimkin V, Blome S, et al. (2015). Comparison of porcine epidemic diarrhea viruses from Germany and the United States. Emerging infectious diseases, 21(3), 493-496. doi: 10.3201/eid2103.141165.

Lara-Romero, R., Gomez-Nunez, L., Cerriteno-Sanchez J.L., Marquez-Valdelamar, L., Mendoza-Elvira, S., Ramirez-Mendoza, H., \& Rivera-Benitez, J.F. (2017). Molecular characterization of the spike gene of the porcine epidemic diarrhea virus in Mexico, 20132016. Virus Genes, 54, 215-224. doi: 10.1007/s11262-017-1528-x.

Li, W., Li, H., Liu, Y., Pan, Y., Deng, F., Song, Y., Tang, X., \& He, Q. (2012). New variants of porcine epidemic diarrhea virus, China, 2011. Emerging infectious diseases, 18(8), 1350-1353. doi: 10.3201/eid1808.120002.

Martelli, P., Lavazza, A., Nigrelli, A.D., Merialdi, G., Alborali, L.G., \& Pensaert, M.B. (2008). Epidemic of diarrhoea caused by porcine epidemic diarrhoea virus in Italy. Veterinary Record, 162, 307-310. doi: 10.1136/vr.162.10.307.

Masiuk, D.M., Sosnitsky, O.I., Nedzvetsky, V.S., Kokarev, A.V., \& Koliada, S.G. (2017). Epidemiology, etiology and gene analysis of spike $\mathrm{S}$ protein of porcine epidemic diarrhea virus infection in Ukraine during 2016-2017. Regulatory Mechanisms in Biosystems, 8(4), 602-610. doi: 10.15421/021792.

Paarlberg, P.L. (2014). Updated estimated economic welfare impacts of porcine epidemic diarrhea virus (PEDV). Dept. Of Agricultural Economics, 14, 2038. doi: 10.22004/ag.econ.174517. 
Park, S., Kim, S., Song, D., \& Park, B. (2014). Novel porcine epidemic diarrhea virus variant with large genomic deletion, South Korea. Emerging infectious diseases, 20(12), 2089-2092. doi: 10.3201/eid2012.131642.

Pasick, J., Berhane, Y., Ojkic, D., Maxie, G., Emburyhyatt, C., Swekla, K. et al. (2014). Investigation into the role of potentially contaminated feed as a source of the first-detected outbreaks of porcine epidemic diarrhea in Canada. Transboundary and emerging diseases, 61(5), 397-410. doi: 10.1111/tbed.12269.

Pensaert, M.B., \& de Bouck, P. (1978). A new coronaviruslike particle associated with diarrhea in swine. Arch Virol, 58(3), 243-247. doi: 10.1007/BF01317606.

Prodanov-Radulović, J., Petrović, T., Lupulović, D., Marčić, D., Petrović, J., Grgić, Ž., \& Lazić, S. (2017).
First Detection and Clinical Presentation of Porcine Epidemic Diarrhea Virus (Pedv) in Serbia. Acta veterinaria, 67(3), 383-396. doi: 10.1515/acve-20170031.

Song, D., \& Park, B. (2012). Porcine epidemic diarrhoea virus: a comprehensive review of molecular epidemiology, diagnosis, and vaccines. Virus Genes, 44(2), 167-175. doi: 10.1007/s11262-012-0713-1.

Sung, M.-H., Deng, M.-C., Chung, Y.-H., Huang, Y.-L. et al. (2015). Evolutionary characterization of the emerging porcine epidemic diarrhea virus worldwide and 2014 epidemic in Taiwan. Infection, Genetics and Evolution, 36, 108-115. doi: 10.1016/j.meegid.2015.09.011.

Wood, E.N. (1977). An apparently new syndrome of porcine epidemic diarrhoea. Vet Rec., 100(12), 243244. doi: 10.1136/vr.100.12.243. 